\title{
Modos de conexão popular no cinema brasileiro pré-64: considerações sobre Vidas secas, Os fuzis e o inacabado Cabra marcado para morrer
}

[ Forms of popular connection in pre-64 brazilian cinema: considerations on Vidas secas, Os fuzis and the unfinished Cabra marcado para morrer

\section{Paulo Bio Toledor}

RESUMO: O ensaio é uma reflexão sobre um aspecto marcante num conjunto de filmes dos anos I960, a saber, a vontade de conexão dos realizadores com as frações populares e marginais do país, algo que aparece no nível temático, estético, político e também produtivo das obras. Depois de algumas considerações sobre Vidas secas (I963), de Nelson Pereira dos Santos, o ensaio se detém em Os fuzis (I964), de Ruy Guerra, e no primeiro Cabra marcado para morrer, filme inacabado de Eduardo Coutinho, cujas filmagens foram interrompidas com a deflagração do golpe, em I964. PALAVRAS-CHAVE: Cinema brasileiro; popular; arte e sociedade. ABSTRACT:
The paper is a freestanding reflection on a striking aspect of a number of films of the I96os, namely the filmmakers' desire to connect with the popular and marginal fractions of the country, something that appears at the thematic, aesthetic, political and also productive level of the works. After some considerations on Vidas secas (I963), by Nelson Pereira dos Santos, the paper focuses on Os fuzis (I964), by Ruy Guerra, and on the first Cabra marcado para morrer, an unfinished film by Eduardo Coutinho, whose shooting was interrupted with the outbreak of the coup in I964. KEYWORDS: Brazilian cinema; engagement; art and society.

Recebido em 22/IO/202I

Aprovado em 04/II/202I

TOLEDO, Paulo Bio. Modos de conexão popular no cinema brasileiro pré-64: considerações sobre Vidas secas, Os fuzis e o inacabado Cabra marcado para morrer. Revista do Instituto de Estudos Brasileiros, Brasil, n. 80, p. 55-67, dez. 202I.

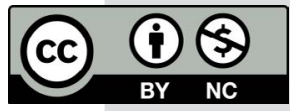

DOI: https://doi.org/Io.II6o6/issn.23I6-90IX.vii8op55-67

I Universidade Federal de Minas Gerais (UFMG, Belo Horizonte, Minas Gerais, Brasil). 
O biênio I963-I964 foi marcante para o cinema no país. Pelo menos quatro filmes decisivos estavam sendo gravados e produzidos no curto espaço de tempo que antecedeu o Golpe de Estado de abril de I964. Todos eles interessados numa figuração crítica das recônditas margens do Brasil, nas quais geografia do sertão, miséria extrema, luta de classes, messianismo e espasmos de revolta pela terra se aglutinavam numa massa própria e, naquele momento, incontornável para compreender a terra em ebulição que se tornara o país. Vidas secas (I963), de Nelson Pereira dos Santos, Os fuzis (I964), de Ruy Guerra e Deus e o diabo na terra do sol (I964), de Glauber Rocha - a chamada trilogia do sertão do Cinema Novo - unem-se pelo gesto de experimentar uma elaboração simbólica do assunto, de modo a ver ali algo sobre o Brasil. Em paralelo, a versão inacabada de Cabra marcado para morrer (I964), de Eduardo Coutinho, parece orbitar o mesmo tipo de interesse.

A organização de obras a partir dessa matéria marginal, localizada fora dos grandes centros urbanos do Sudeste, passou a ser uma tendência em quase toda a produção artística engajada naqueles anos que antecederam o golpe. Sobretudo no campo do teatro, um ambiente que, naquele momento, era muito próximo ao do cinema, com diretores, atores e técnicos circulando entre as duas linguagens. Os principais grupos de esquerda, como o Teatro de Arena de São Paulo e os grandes movimentos de democratização da arte, como o Centro Popular de Cultura (CPC) da UNE e o Movimento de Cultura Popular (MCP) de Pernambuco, centralizavam suas criações cada vez mais no interesse pelas margens agrárias do país (VILLAS BÔAS, 2009). A partir de I96I, diversas montagens sobre o conflito pela terra ou sobre a exploração do lavrador nas beiras do Brasil se sucediam e inspiravam umas às outras. Um exemplo emblemático é Mutirão em Novo Sol, uma peça escrita coletivamente sobre um levante de lavradores no interior paulista, que foi motivo de importantes montagens até I964 (NEIVA; TOLEDO, 20I5). A versão da peça produzida pelo CPC paulista se apresentou no I Congresso Nacional de Lavradores e Trabalhadores Agrícolas em Belo Horizonte, e foi uma experiência marcante para o jovem Eduardo Coutinho, que participou da montagem e logo depois entrou para o setor de cinema do CPC no Rio de Janeiro (COUTINHO, 2000, p. 96). Já a versão do CPC da Bahia, de I963, uniu setores de teatro e cinema num tipo ainda desconhecido de linguagem híbrida politizada. Como parte do espetáculo, foi produzido por Geraldo Sarno e Orlando 
Senna um filme cuja estética experimental teria influenciado Glauber Rocha, segundo o próprio, na criação de Deus e o diabo na terra do sol. (ROCHA, 2004, p. 476).

Os primeiros anos da década de I960, portanto, abarcaram uma produção artística crescentemente marcada por essa perspectiva. $O$ ineditismo do conjunto não é o ângulo temático propriamente. A novidade foi, antes, o pressentimento de que ali, na luta pela terra, na exploração do trabalho no campo, na miséria extremada, encontrava-se o principal ponto de tensão do Brasil, e que, por conseguinte, dali nasceria o futuro - como sugere o marcante verso reiterado em Deus e o diabo na terra do sol (I964): "o sertão vai virar mar/ o mar virar sertão". A fração geográfica, social, histórica focalizada nas obras ganhava estatuto de imagem reduzida do país - seja sua face de barbárie perpétua, seja o horizonte de transformação que essa nossa luta de classes brotada da terra apresentava.

Esse conjunto de obras teatrais e cinematográficas interessadas pelas margens do Brasil estava ligado também a um ambiente de alta voltagem política que impelia os artistas para um debate complexo e estimulante sobre as formas de vinculação entre as frações populares/marginais do país, que apareciam como assunto nas obras, e certa intelectualidade artística esclarecida, que as produzia. Embora muito estigmatizado posteriormente, esse tipo de perspectiva provocou um intenso debate sobre o lugar social da arte e impulsionou uma série de experiências que buscaram, cada uma a seu modo, enfrentar o problema. Os referidos filmes produzidos entre I963-I964, assunto deste ensaio, podem ser analisados à luz dessa questão.

\section{A câmera e a fome}

Em certa altura do filme Vidas secas, de Nelson Pereira dos Santos, o personagem Fabiano, após sair de um período humilhante na prisão, é convidado a integrar um grupo de cangaceiros. É uma cena curta, mas notável, pois contrasta com o acúmulo de miséria, humilhações e abandono enfatizados durante toda a trajetória da família sobrevivendo entre uma seca e outra na década de I930. O pequeno fragmento revela, de repente, a possibilidade real de contrapor-se ao mundo de injustiças a que Fabiano e sua família estavam submetidos. Trata-se de um desvio com relação ao romance de Graciliano Ramos, no qual o cangaço é apenas um desejo difuso do personagem, depois de apanhar dos soldados e passar a noite na cadeia:

Carregaria a espingarda e daria um tiro de pé de pau no soldado amarelo. Não. O soldado amarelo era um infeliz que nem merecia um tabefe com as costas da mão. Mataria os donos dele. Entraria num bando de cangaceiros e faria estrago nos homens que dirigiam o soldado amarelo. Não ficaria um para semente. Era a ideia que lhe fervia na cabeça. (RAMOS, 2008, p. 50).

Obviamente, Fabiano nega, no filme, o ingresso no cangaço - se não o fizesse, a versão de Nelson Pereira dos Santos se afastaria de maneira incontornável do romance. Mas a cena é destacada na película. Ela aparece como a possibilidade latente, ao alcance mesmo das mãos, de um revide exclusivamente de classe contra a or- 
dem dos coronéis, que seca a vida tanto quanto o sol. A cena pode ser lida assim, ou seja, como uma fugaz aparição de uma revolta genuinamente popular. Entretanto, a forma cinematográfica do filme pressupõe outra presença. É o olho da câmera que organiza, seleciona, recorta de fora as cenas da miséria. Essa mirada, técnica e especializada, no filme em questão, passa a ser ostensivamente autoral. Como diz Glauber Rocha (2004, p. 62) em análise entusiasmada do filme: "mais do que em Graciliano Ramos, Vidas secas, em filme, é a primeira confissão autobiográfica de Nelson Pereira dos Santos". Com efeito, a aparição de um possível revide de classe, ou seja, nascido no âmago da miséria e impulsionado somente por ela, é, paradoxalmente, sugerido "de fora" por essa atitude marcante do autor, que "se lança à conquista dos meios e do filme" (ROCHA, 2004, p. 62) e propõe uma tese.

No primeiro plano de Vidas secas, a imagem mostra um horizonte do sertão. Ao longe, assistimos às pequenas silhuetas de Fabiano, Sinhá Vitória e filhos caminhando em direção à câmera. No final, o mesmo plano. Mas a família agora se retira por aquele caminho que chegou até nós, afasta-se da objetiva, e o filme termina. O objeto da miséria, da fome, da seca é o que cria as balizas dentro das quais o filme se desenvolve. Instaura-se um tipo de centralidade para aqueles que sempre ocupam as margens do país e da vida social. Ao mesmo tempo, é a perspectiva da câmera que enquadra esse objeto. E faz isso de modo a sublinhar o ponto de vista autoral, a perspectiva do artista-autor-intelectual. De modo que a integração de classe se realiza nesse gesto, entre a matéria (o sertão, a pobreza) e a técnica cinematográfica capaz de desbravar o sertão. Por um lado, o povo iletrado se subordina à estrutura avançada do cinema, por meio do qual o autor expõe de forma crítica e artística a exploração. Em contrapartida, ao mesmo tempo em que controla o trabalho criativo, o cineasta se coloca à disposição da única força capaz de objetivamente mudar a história. A breve referência de Sinhá Vitória - quase a última fala do final do filme - ao intelectual Seu Tomás é logo replicada por Fabiano:

Grandes coisa, Seu Tomás sabia muito, é... Mas quando botou o pé no mundo se acabou no caminho. A leitura serviu pra alguma coisa? Serviu? Não serviu pra ele aguentá nem duas léguas. (VIDAS, I963).

Quem diz é Fabiano. Entretanto, o autor diz junto com ele, num tipo de ativa contradição plasmada na própria estrutura técnico-criativa do filme. É a técnica e a assinatura autoral do filme - "a liberdade do ritmo ao palpitar do coração [...] que, de dentro para fora, determina um estilo de mise-en-scène e se define" (ROCHA, 2004, p. 63) - que dá liga para esse enquadramento popular, seco, famélico. A atitude autoral se realiza na conjugação com essa força marginal e sistematicamente excluída, que, por sua vez, ganharia a chance de expansão no encontro com a técnica e a sensibilidade do artista. Estariam, então, juntos na "luta contra o coronel" e no desejo de "conquistar o sol da beleza transcendente" (ROCHA, 2004, p. 62).

A ênfase dada por Glauber Rocha a esse aspecto autoral de Vidas secas também aponta para suas próprias experiências. As novas maneiras de organizar a produção fílmica resultam numa estética própria, forjada ali na miséria de condições e no espírito de transformação. Uma estética que se reconhece na força dos desejos de 
integração explosiva de classe. Quando Glauber Rocha filma Deus e o diabo na terra do sol, é ele mesmo quem opera a câmera e, com ela, segundo Ismail Xavier (2007, p. I02), desenvolve um "comportamento que imita a própria disposição das personagens". 0 ponto de vista do autor/narrador sobre a margem, a miséria, o messianismo no país constitui uma poética cinematográfica própria:

seu andar desequilibrado, sua liberdade de movimentos e sua trepidação denunciam uma subjetividade por trás da objetiva, revelam uma palpitação nas operações de quem narra de modo a nivelar sua experiência à das personagens (XAVIER, 2007, p. IO3).

Aqui, a distância entre o especialista e as frações populares filmadas busca ser dirimida por esse "nivelamento" entre o artista-intelectual e o sertão representado, o que aparece como a cristalização em forma própria dos desejos de vinculação tão presentes no período. O manifesto A estética da fome, escrito em I965 por Glauber Rocha (2004, p. 63-67), é mais um passo de formalização desse impulso. A fome é que constituiria o gesto artístico letrado, num suposto paradoxo que é, por sua vez, a força do procedimento. Para Ismail Xavier (2007, p. I3):

A preposição 'da', ao contrário da preposição 'sobre', marca a diferença: a fome não se define como tema, objeto do qual se fala. Ela se instala na própria forma do dizer, na própria textura das obras.

Ao fim e ao cabo, a fração de explorados não é objeto ao qual se estende a mão, mas passa a ser, ao menos em teoria, a matéria fundamental do gesto artístico - passa a ser a própria estética. Dito de outro modo, esse desejo de aproximação da fome ultrapassou o campo meramente temático e tornou-se um pressuposto estruturante das obras. Buscou-se incandescer ao máximo o paradoxo da distância aparentemente intransponível entre o povo representado e o artista, e, assim, instaurar a crise no núcleo artístico das criações, até revertê-la num tipo de poética nova. Cinema Novo. Mas ainda está lá, e não deixa de ser incômoda, a contradição.

\section{$O$ avesso da conexão}

Filmado no mesmo período, Os fuzis, de Ruy Guerra, coloca o problema de outro modo e, com espanto, reflete sobre os desejos de integração por ângulo radicalmente diverso. A obra, finalizada no início de I964, destaca-se do bloco de filmes e peças do período por uma espécie de trato singular com a matéria. $O$ ambiente é o mesmo sertão; o interesse é também a miséria, o messianismo, a exploração promíscua, a luta social latente, a barbárie, e tudo isso como imagem reduzida do país. Mas aqui a forma e o ângulo de olhar são bastante diferentes - o que faz, inclusive, desconfiar da fórmula "trilogia do sertão" para se referir ao conjunto de filmes.

A história é relativamente simples. Em meio a uma seca no Nordeste, no povoado de Milagres, no sertão da Bahia, um destacamento militar é convocado para proteger as mercadorias do armazém da cidade, rodeada, por sua vez, por uma multidão de 
miseráveis famintos, devotos de um boi santo que supostamente fará chover. No meio disso, um ex-soldado, motorista de caminhão e chamado de Gaúcho, se indigna com a situação, tenta um inócuo gesto de revolta e acaba morto por seus antigos colegas de ofício.

Contudo, há uma especificidade formal na maneira como a película se desenvolve. Como aponta Roberto Schwarz (2008, p. 30), o filme se organiza em torno de uma aparente dissonância entre as partes: "como se de cena em cena alternassem duas fitas incompatíveis: um documentário da seca e da pobreza, e um filme de enredo".

Nesse sentido, e ainda segundo o crítico, a miséria é documentada não com a "compaixão" diante do triste e trágico destino daqueles que a sofrem, mas como "uma aberração" (SCHWARZ, 2008, p. 30). Flagelados da seca cultuam um boi santo enquanto suas crianças morrem de fome. Untam-se com as fezes do animal esperando a chuva milagrosa. Quando a situação parece humanamente insustentável, o sacerdote proclama: "Deus é misericordioso e põe sempre à prova a resignação de seus eleitos” (OS FUZIS, I964). Os pobres habitantes dessa margem do país sobrevivem em estranha inércia e imobilidade; os poucos que falam são literalmente cegos e sempre aguardam algo. Em torno de uma das cenas do "filme de enredo", vemos o povo da cidade em movimento aparentemente irracional, cantando enquanto dá infinitas voltas ao redor da igreja. Simbólico círculo sem fim. Alguém diz que estão "pagando promessas", o que, em suma, significa que agradecem algo numa inércia rotativa de preces, mesmo diante da desumanização oriunda da seca e da fome. Na maior parte das cenas, os moradores pobres da cidade de Milagres aparecem como massa documental amorfa, gravitando em torno do enredo que envolve os militares. Em dado momento, Gaúcho discute com o soldado Mário sobre o povo, a fome e a exploração a que estão submetidos. A câmera acompanha o diálogo dos dois, mas em torno deles estão dezenas e dezenas de moradores pobres sentados no chão, aguardando nada. Ambos discutem e falam do povo andando em torno de um povo imóvel, desinteressado e silencioso - que, ainda por cima, é mostrado de forma documental.

Se Sinhá Vitória, no filme Vidas secas, consegue formular a situação animalizada a que estão submetidos - "por que havemos de ser sempre desgraçado, fugindo no mato que nem bicho?” (VIDAS, I963) -, em Os fuzis, os flagelados não possuem esse estatuto de sujeito consciente que permite elaborar algo sobre sua situação. Eles são, ao contrário, seres estragados pela animalização, em uma funesta sobrevivência que é somente espera. No final, quando a situação parece enfim na iminência de explodir, a câmera de Ruy Guerra filma os habitantes como piranhas que se amontoam em torno do antigo boi santo, o qual, quando a fome chega ao limite, "deixa de ser santo e deixa de ser boi" (OS FUZIS, I964). E isso ao mesmo tempo em que dezenas de caminhões carregados de alimentos deixam o armazém da cidade. A expressão boi de piranha parece encontrar aqui uma materialização trágica.

Para Roberto Schwarz (2008, p. 30), o filme "tira sua força dessa distância", dessa identificação impossível para com a massa trágica dos flagelados e moradores pobres. Isso porque a representação típica da pobreza tende a estabelecer "um contínuo psicológico onde não há contínuo real: o sofrimento e a sede do flagelado nordestino, vistos de perto e de certa maneira, são meus também”. O problema do qual escapa Os fuzis é que: 
Na identidade perde-se a relação, desaparece o nexo entre o Nordeste e a poltrona em que estou [...] não saio como beneficiário, que sou, de uma constelação de forças, de um empreendimento de exploração. (SCHWARZ, 2008, p. 29-30).

Assim, paradoxalmente, a distância documental da miséria é também a forma de integrá-la a um sistema maior, a um "empreendimento de exploração". Isso porque, no filme de Ruy Guerra, "miséria e civilização técnica estão constelados" (SCHWARZ, 2008, p. 3I), o que é outra forma de dizer que, por aqui, progresso e barbárie andam juntos e dependem um do outro para seguir existindo. Ao contrário de como aparece em Vidas secas ou em Deus e o diabo na terra do sol, por exemplo, a integração aqui se dá por via negativa e é um problema.

Essa constelação entre "miséria e civilização" é sugerida durante o filme numa série de inflexões e contrastes entre as partes. Logo no início, a forma de documentário explicita-se quando uma velha cega conta, diretamente para a câmera, sua história trágica. Durante a narrativa ela responde perguntas (que não ouvimos) vindas de trás da câmera, do documentarista/entrevistador. Mas, ao mesmo tempo, os dois campos que parecem tão distantes estão integrados: a velha toca um instrumento rudimentar feito de lata, a música é uma espécie de marcha que, por sua vez, marca o ritmo da cena seguinte, justamente a chegada dos soldados para proteger o armazém de Milagres. Centro e margem, margem e centro, numa estranha simbiose sonora.

Os soldados entram na cidade sempre com seus fuzis a tiracolo. E tal instrumento de guerra, evocado, não por acaso, no título do filme, é aqui marca constitutiva da civilização técnica - como sublinha uma das cenas mais marcantes, quando um dos militares desmonta a arma e a descreve de forma pormenorizada, em toda sua grandeza tecnológica, diante de lavradores estáticos. Não obstante, sobretudo ali no povoado de Milagres, o fuzil serve para manter o atraso, a exploração e o mandonismo. Serve para garantir a persistência da barbárie. Os soldados são forças públicas que chegam ao longínquo local para realizar uma tarefa de ordem privada, a defesa da propriedade, a guarda do armazém de Vicente Ferreira em tempos de seca e fome. Grosso modo, o Exército brasileiro cumpre as vezes do jagunço. São sentinelas do proprietário. Arbítrio, violência a soldo e descompromisso com a lei passam a ser, justamente, o modus operandi dos representantes da norma, da ordem de Estado. Num momento do filme, o soldado Mário narra operações de rotina em outra parte do país, quando expulsou e matou posseiros que reivindicavam terra. Então reflete, em estúpida ingenuidade: "engraçado, eles achavam que a terra era deles” (OS FUZIS, I964). Técnica e barbárie se conjugam também na fala do sargento ao dono do armazém: "cada fuzil alcança I.200 metros. Se for preciso varro à bala toda essa região”. O amálgama de ordem e desordem², típico das práticas do jagunço, aparece não como resquício arcaico colonial, mas como fundamento da civilização.

A ideia que animou boa parte da produção artística brasileira desde a década de I940 fundamentou-se mais ou menos na observação das margens do país como imagem reduzida do todo. Afinal, as relações perversas dali persistiriam em seu centro ou, na melhor das hipóteses, seriam uma chaga aberta nas tentativas de avanço do país. Em Os fuzis, há um vislumbre do reverso dessa lógica: no povoado de Milagres, é o centro,

2 Faz-se referência aqui ao clássico ensaio de Antonio Candido, Dialética da malandragem (20Io). 
a civilização, o progresso que está presente nas margens do país e que dita o ritmo de sua inércia. Num momento do filme, vemos a negociação de uma menina de I4 anos. A priori, soa como resquício do atraso brutal, da escravidão renitente - o que não deixa de ser verdadeiro. Mas os termos da negociata são modernos. Vemos primeiro a dúvida do comprador (Gaúcho): "tá muito caro"; seguida da réplica do negociante (o pai da menina): "um cavalo tá valendo mais do que isso [...]. Com bom trato vai ficar valendo mais" (OS FUZIS, I964). Por detrás do contexto desumano, há tino comercial. A miséria, excrescência do mercado, torna-se, ela mesma, mercadoria. Assim como numa das cenas finais, quando o dono do armazém se despede do sargento com um "até o ano que vem" e deixa escapar: "tomara que dê uma boa seca" (OS FUZIS, I964). Ora, a especulação com a miséria, o estoque de mercadoria, o açambarcamento, são procedimentos com alto potencial de lucratividade e que se valem justamente da miséria extrema como elemento de valorização, moeda de troca, mercadoria. Aqui, quanto maior a desgraça, mais altas são as cifras.

O tipo de integração centro-periferia flagrada pelo filme nega tanto o dualismo desenvolvimentista do período (fundamentado nos binômios: atraso versus progresso ou desenvolvido versus subdesenvolvido) como a fé messiânica num levante das margens que, ora ou outra, emergiriam apesar da barbárie a que estão submetidas, ou justamente por causa dela. Ao contrário disso, o filme vê o Brasil conjugando desde sempre modernização e atraso, centro e margem, civilização e barbárie, cidade e sertão, e, por conseguinte, ordem e desordem, lei e mandonismo (ambos empunhando o fuzil), cordialidade e arbítrio.

Em outro momento, Roberto Schwarz, no livro Um mestre na periferia do capitalismo (2000, p. I3), formula assim a questão: "as marcas clássicas do atraso brasileiro não deviam ser consideradas como arcaísmo residual”, ao contrário, deveriam ser vistas "como parte integrante da reprodução da sociedade moderna, ou seja, como indicativo de uma forma perversa de progresso". Faz coro com o economista e sociólogo Francisco de Oliveira, que, em sua Crítica à razão dualista (2003, p. 32), escreve: "o processo real [brasileiro] mostra uma simbiose e uma organicidade, uma unidade de contrários, em que o chamado 'moderno' cresce e se alimenta da existência do 'atrasado". Por aqui, o capitalismo cresce por "elaboração de periferias" (OLIVEIRA, 2003, p. 43).

Convivendo com os desejos de integração entre classe média intelectualizada de esquerda e o povo, na abordagem de Os fuzis percebemos, com espanto, que já existe há muito uma brutal conexão galvanizada entre frações análogas da sociedade.

Daí se forma o paradoxo, ou a dialética, que torna a obra decisiva: a distância da margem retratada, na forma do filme, a conecta, em negativo, à civilização técnica. Essa a imagem de país que emerge da organização estrutural em Os fuzis. Ao mesmo tempo, a película de Ruy Guerra também faz ver o elo entre a miséria e o público intelectual ao qual, bem ou mal, o filme se destina, e que faz parte - quer queira, quer não - da ordem progressista, moderna e citadina. Roberto Schwarz (2008, p. 32), no já citado ensaio sobre o filme, comenta: 
Os soldados são como nós. Mais, são os nossos emissários no local, e gostemos ou não, a sua prática é a realização de nossa política. É nela que estamos em jogo, muito mais que no sofrimento e na crendice dos flagelados.

Um momento estranho e perverso do filme mostra uma cena de sexo entre o soldado Mário (o mais esclarecido e humano dentre todos) e Luiza, moradora de Milagres. A cena é filmada de tal modo que não sabemos se há consentimento ou se trata de um estupro. Soa como imagem dessa conexão de classes, um misto de amor e abuso. Numa mirada, estão lá tanto o desejo do intelectual esclarecido pelos encantos e a força singular do povo como o abuso econômico que sustenta a ordem civilizacional da qual ele faz parte. No final do filme, a menina pergunta a Mário: "você volta?" e ele diz, convicto: “não". Ao mesmo tempo, marca doída da relação desigual e recusa solitária a manter operante a perversa ordem da qual ele faz parte.

\section{Por um trabalho novo}

O interesse por uma conexão com as frações populares, contudo, não era feito somente de idealismo ou mistificação. Na altura da estreia de Os fuzis, outra experiência, esta incompleta, realizava-se no Engenho Galileia, em Pernambuco. Nos primeiros meses de 1964, Eduardo Coutinho começava as filmagens de Cabra marcado para morrer. O projeto nascera em I962, logo após o assassinato do líder camponês João Pedro Teixeira, em Sapé, na Paraíba. Coutinho, naquela altura, viajava com o Centro Popular de Cultura (CPC) do Rio de Janeiro na chamada UNE-Volante, um projeto da entidade estudantil que atravessou o país promovendo debates, apresentações de teatro e outras ações político-culturais. Durante a passagem pela Paraíba, o jovem interessado por cinema filmou alguns comícios de Elizabeth Teixeira, viúva de João Pedro. Ali começou a pensar em um filme sobre o assunto. Inicialmente, a ideia era algo baseado nos poemas Morte e vida severina e Cão sem plumas, de João Cabral de Melo Neto. $\mathrm{O}$ autor chegou a autorizar o projeto, mas, "atemorizado talvez pelo que naquela época se dizia do CPC da UNE, desautorizou a licença e eu fiquei sem pai nem mãe" (COUTINHO, 20I3, p. I84).

Outro poema serviu então de mote para o projeto, João Boa-Morte. Cabra marcado para morrer, escrito por Ferreira Gullar em I962, por sugestão de Oduvaldo Vianna Filho, o Vianinha, logo após a morte do líder camponês. Em uma estrutura de rimas fáceis, a forma do poema parece emular uma cantoria popular nordestina ou um breve romance de cordel para contar a trajetória de um camponês chamado João. Em certa altura, contudo, o tom algo genérico, que mostrava o sofrimento de um João dentre tantos outros, "uma história banal/ em todo aquele Nordeste" (GULLAR, I980, p. III), ganha uma especificação documental. João passa a ser "Pedro Teixeira", que "lutara ao lado de [Francisco] Julião" (GULLAR, I980, p. II8), o advogado que foi figura decisiva na criação das Ligas Camponesas. Esse trânsito rápido entre ficção e atmosfera documental presente no andamento do poema também inspirava a estrutura do primeiro roteiro de Cabra marcado para morrer. A discussão sobre o roteiro, aliás, foi 
realizada coletivamente, dentro do CPC, em I963, com participação ativa de Vianinha (COUTINHO, 2000, p. 95), no momento em que Gullar presidia o movimento.

Em I98I, Eduardo Coutinho retomará o material inacabado para conduzir aquele que talvez seja o seu documentário mais importante, também nomeado Cabra marcado para morrer, e que estreou em I984. No início do filme, são projetados fragmentos do roteiro de I963. É possível notar, nas passagens do texto, uma estrutura épica-popular, também derivada do poema, como a presença de um narrador, anotado como "cantador". É um narrador interno ao filme, que era quem, provavelmente, faria as conexões entre a perspectiva ficcional e a documental. Não há qualquer registro dessa estrutura narrativa operando, isto é, não foram recuperadas cenas em que aparecem esse "cantador". Sua inserção no roteiro, contudo, dá pistas da inventividade que aquele projeto continha.

No final de I963, o CPC conseguiu verbas para o projeto e costurou uma parceria com o Movimento de Cultura Popular (MCP) de Pernambuco, que coproduziria o filme. As filmagens começaram no início de I964. A ideia era que fossem realizadas em Sapé, na Paraíba, no próprio local e com os próprios lavradores que participaram do processo de luta que levou ao assassinato de João Pedro Teixeira, em I962. Mas em janeiro de I964, começou outro levante na região. O conflito terminou com mais de dez mortos e forte presença militar, inviabilizando as filmagens (COUTINHO, 20I3, p. I84). Decidiram então ir para Vitória do Santo Antão, em Pernambuco, filmar no Engenho Galileia, um dos nascedouros das Ligas Camponesas e onde o MCP poderia apoiar mais ativamente na logística das filmagens.

Tudo indica que a ideia era enfatizar os aspectos documentais do filme na película de ficção. Os "atores" eram camponeses da região (originalmente, aliás, a ideia era filmar com companheiros de João Pedro Teixeira, na Paraíba), e Elizabeth Teixeira, viúva do líder camponês, participaria do filme "representando" ela mesma. Algo sem paralelo até então, embora vibrasse ali o mesmo tipo de mobilização documental que aparece nas cenas de Os fuzis. Mas ao contrário do filme de Ruy Guerra, que apresentava uma furiosa curiosidade pelo estrago social causado pela miséria, no inacabado Cabra marcado para morrer, o aspecto documental ressaltaria a força e a autonomia daqueles lavradores.

No documentário de 1984, o narrador (por sinal, Ferreira Gullar) afirma, de passagem, que os camponeses que participaram das filmagens em I964 podiam dedicar ao filme "um tempo que lhes pertencia" (CABRA, I984). Na maior parte, eles eram remanescentes da luta de mais de quatro anos que culminou na desapropriação do Engenho Galileia e alavancou a luta das Ligas Camponesas naquela região. Ou seja, os participantes do filme, envolvidos que estavam naquele momento de grande efervescência social e significativos ganhos do trabalho sobre o capital rural do país, tinham desbravado condições que permitiam a eles produzir cultura. $O$ filme também seria testemunha disso.

Com efeito, essas não são características quaisquer da estética do filme. São aspectos que engendravam transformações no modo de trabalho criativo. O roteiro, por exemplo, não foi totalmente fechado por Coutinho antes do início das filmagens. O texto apresentava espaço para aberturas colaborativas, nas quais os lavradores, a partir de improvisações teatrais, escreviam as falas e determinavam o andamento das cenas. Um exemplo desse procedimento aparece no documentário posterior, em 
que Coutinho insere no filme uma das cenas recuperadas de I964, na qual um grupo de posseiros vai questionar o capataz da propriedade. A cena restaurada foi dublada em 1984 e incluída no documentário. Durante sua apresentação na tela, o narrador expõe a especificidade do material: "os diálogos da sequência foram criados pelos próprios atores através de improvisações feitas antes das filmagens” (CABRA, I984). Também Eduardo Coutinho (2000, p. 99) relata, em entrevista, anos mais tarde:

A gente fez um laboratório com os camponeses, que foi uma coisa maravilhosa. Aquela cena que está lá do feitor, não tem uma palavra do diálogo que não seja exatamente dita por eles. Pegamos um deles - o que faz o administrador -, botamos seis caras em volta, no refeitório da casa, e ficaram improvisando.

A novidade espantosa na forma de produção aparecia como um novo passo no projeto de conexão entre classe média engajada e frações sociais exploradas. A conexão aqui não é uma questão temática ou formal, está ligada aos modos de trabalho e de produção cinematográfica. O que, por sua vez, incidiria na estrutura da película e nos modos de lidar com o assunto. Porém, dinâmicas como essa, que trabalhavam junto com trabalhadores, foram imediatamente alvo dos militares depois do golpe. Cabra marcado para morrer nunca pôde ser concluído. No primeiro dia de abril de I964, as filmagens foram interrompidas e Galileia foi invadida pouco depois por tropas do Exército. Os participantes tiveram de fugir como puderam?3

Numa entrevista de I976, anos antes de viabilizar a retomada em forma de documentário, Coutinho fala sobre o projeto interrompido da década de I960 e afirma: "O filme se tornou impossível porque vivia de uma realidade que acabou em 3I de março de I964" (COUTINHO, 20I3, p. I85). Ele tinha razão. É uma experiência que deriva e se apoia naquelas condições bastante específicas, em torno de grandes movimentos como os CPCs e o MCP. Em Cabra marcado para morrer, o lavrador aparece como sujeito do processo criativo, o que ecoa aquele que talvez tenha sido o coração do trabalho de alfabetização no MCP, conduzido por Paulo Freire nos primeiros anos da década de I960. Embora o educador tenha se referido pouco ao MCP em seus livros, o trabalho que ele realizou ali foi decisivo em suas formulações futuras (COELHO, 2002), por exemplo, aquelas do clássico Pedagogia do oprimido, escrito em I968 e publicado no Brasil em I974. Em linhas gerais, no seu trabalho prático de estabelecer dinâmicas de aprendizagem popular no MCP, Freire questionou aquilo que chamará mais tarde de educação “bancária”, uma ideia passiva de aprendizagem, sempre de cima para baixo, que transforma os educandos "em 'vasilhas', recipientes a serem 'enchidos' pelo educador" (FREIRE, I974, p. 66). Em contrapartida, propunha um modo de educação cujo fundamento é instaurar um processo de aprendizagem no qual o educando é sujeito, nunca objeto; é ator, não espectador. Ao invés de

3 Na fuga, segundo o diretor, "perdeu-se praticamente tudo" (COUTINHO, 20I3, p. I85). A retomada do filme, em I98I, agora com um viés reflexivo de mirada ao passado engajado, só foi possível porque parte do material filmado já tinha sido enviada para laboratório no Rio de Janeiro e porque, quando o proprietário das câmeras recuperou o equipamento com o Exército, notou que a câmera não havia sido aberta e, no seu chassi, ainda havia um rolo de filme. 
"ensinar" o conteúdo, trabalha-se buscando "decodificar a linguagem", de modo a liberar o conhecimento para ser reinventado, transformado ou mesmo criticado. Um aprendizado ativo que transforma simultaneamente educadores e educandos. Para Freire (I974, p. 57): “A ação política junto aos oprimidos tem de ser, no fundo, 'ação cultural' para a liberdade, por isto mesmo, ação com eles”.

A afirmação projeta um tipo de conexão ativa de classes. Nas práticas experimentais em torno de grandes movimentos como o CPC e o MCP, essa também foi a tônica, em muitos momentos, na forma de produzir arte. Cabra marcado para morrer compõe e dá notícias desse ambiente avançado que transformava os sentidos produtivos da criação. É um projeto inacabado, mas que anuncia outra perspectiva de trabalho. Algo que, todavia, após o golpe de I964, não só é interditado como também vai saindo do radar dos artistas e dos críticos. Subtraído o ângulo produtivo e histórico da análise, o Cabra marcado para morrer de I964 passa a ser visto como um tipo de fragmento arqueológico de uma estética ingênua e panfletária, até uma tolice juvenil, perto da grandeza criativa identificada no documentário de vinte anos depois ${ }^{4}$.

Ironicamente, no parecer da censura sobre o documentário, o burocrata constata que "a obra é tendenciosa e saudosista, politicamente, tendo contudo perdido muito da potencialidade politizante, que foi deteriorada pelo tempo, que tudo consome"5. O filme é liberado para maiores de I8 anos. A potencialidade politizante estava, como talvez tenha percebido o ambíguo censor, na já inexistente possibilidade de articulação produtiva com os lavradores. Não deixa de ser uma vitória permanente do golpe a maneira como aquele tipo de experiência, bem como os debates sobre os modos de conexão popular da arte e as tentativas de realizá-los têm sido, aparentemente, deteriorados e consumidos pelo tempo.

\section{SOBRE O AUTOR}

Paulo Bio Toledo é professor da Faculdade de Letras

da Universidade Federal de Minas Gerais (FALE/

UFMG) na área de Literatura e Outras Artes.

paulobio@ufmg.br

https://orcid.org/oooo-0003-2025-7586

4 Alguns textos compilados por Milton Ohata no livro Eduardo Coutinho (OHATA, 20I3) dão notícias dessa perspectiva. Por exemplo, as resenhas escritas na década de I980, Do épico-pedagógico ao documentário, de Marilena Chauí, e No cinema, uma saga camponesa, de Sérgio Augusto; ou ainda, escrito mais recentemente, Cabra marcado para morrer, cinema e democracia, de Tales A. M. Ab’Sáber. O próprio Coutinho (I999, p. 29) assumiu essa posição. Em entrevista de I999, ele diz: “a primeira fase do Cabra era alienação pura. Era uma visão tola [...]. Já no Cabra definitivo (I984), acho que toda a ambiguidade está presente”.

5 O documento é citado por Eduardo Escorel (20I3, p. 497) no texto Triunfo e tormento. 


\section{REFERÊNCIAS}

CABRA marcado para morrer. Direção: Eduardo Coutinho. Mapa, I984.

CANDIDO, Antonio. Dialética da malandragem. Revista do Instituto de Estudos Brasileiros da USP, São Paulo, n. 8, I970, p. 67-89.

COELHO, Germano. Paulo Freire e o Movimento de Cultura Popular. In: ROSAS, P. (Org.). Paulo Freire: educação e transformação social. Recife: UFPE, 2002, p. 3I-95.

COUTINHO, Eduardo. A caminho do Nordeste de Cabra Marcado para Morrer [entrevista concedida a Ana Maria Galano]. Cadernos de Antropologia e Imagem, v. II, n. 2, Rio de Janeiro: UERJ, 2000, p. 9I-Io9.

COUTINHO, Eduardo. Exercícios para Cabra marcado para morrer [entrevista concedida a José Marinho de Oliveira]. In: OHATA, Milton (Org.) Eduardo Coutinho. São Paulo: Cosac Naify, 20I3, p. I82-2Io.

COUTINHO, Eduardo. Fé na Lucidez [entrevista]. Sinopse, Dossiê Documentário, n. 3, ano I, dez. I999, p. 20-29.

DEUS e o diabo na terra do sol. Direção: Glauber Rocha. Copacabana Filmes, I964.

ESCOREL, Eduardo. Triunfo e tormento. In: OHATA, Milton (Org.) Eduardo Coutinho. São Paulo: Cosac Naify, 20I3, p. 482-505

FREIRE, Paulo. Pedagogia do oprimido. Rio de Janeiro: Paz e terra, I974.

GULLAR, Ferreira. João Boa-Morte [I962]. In: Toda poesia (I950-I980). Rio de Janeiro: Civilização Brasileira, I980, p. III-I23.

NEIVA, Sara Mello; TOLEDO, Paulo Bio. Mutirão em Novo Sol e o experimentalismo político no teatro brasileiro da década de I960. Revista Aspas, [S. l.], v. 5, n. 2, p. 67-80, 20I5. DOI: Io.II606/issn.2238-3999. v5i2p67-80

OHATA, Milton (Org.) Eduardo Coutinho. São Paulo: Cosac Naify, 2013.

OLIVEIRA, Francisco de. Crítica à razão dualista. São Paulo: Boitempo, 2003.

OS FUZIS. Direção: Ruy Guerra. Copacabana Filmes, I964.

RAMOS, Graciliano. Vidas secas. Edição comemorativa 70 anos. Rio de Janeiro: Record, 2008.

ROCHA, Glauber. Revolução do cinema novo. São Paulo: Cosac Naify, 2004.

SCHWARZ, Roberto. O cinema e Os fuzis. In: O pai de família e outros estudos. São Paulo: Companhia das Letras, 2008, p. 29-37.

SCHWARZ, Roberto. Um mestre na periferia do capitalismo. 4. ed. São Paulo: Duas Cidades/Ed. 34, 2000.

VIDAS secas. Direção: Nelson Pereira dos Santos. Herbert Richers, I963.

VILLAS BÔAS, Rafael Litvin. Teatro político e questão agrária, I955-I965: contradições, avanços e impasses de um momento decisivo. Tese (Doutorado em Teoria Literária e Literaturas) - Instituto de Letras, UnB, Brasília, 2009.

XAVIER, Ismail. Sertão mar: Glauber Rocha e a estética da fome. São Paulo: Cosac Naify, 2007. 